Bartın Üniversitesi İktisadi ve İdari Bilimler Fakültesi Dergisi, 2021, Cilt 12, Sayı 23

Bartın University Journal of Faculty of Economics and Administrative Sciences, 2021, Volume 12, Issue 23

E-ISSN: 2148-2497

http://iibfdergi.bartin.edu.tr/

https://dergipark.org.tr/tr/pub/bartiniibf

Araştırma Makalesi, Gönderim Tarihi: 18.02.2021; Kabul Tarihi: 22.05.2021

\title{
Elektronik Ticaret Alışverişinde Tüketicilerin Algıladığı Riskin Ölçümlenmesi: Çok Boyutlu Bir Yaklaşım ${ }^{1}$
}

\author{
Dr. Öğr. Üyesi İlhami TUNCER \\ Karamanoğlu Mehmetbey Üniversitesi, İIBF, Uluslararası Ticaret ve İşletmecilik Bölümü, \\ ituncer@kmu.edu.tr, Orcid ID: 0000-0002-6883-4461
}

\section{Öz}

Covid-19 salgınının etkisiyle elektronik ticaret (e-ticaret) sektörünün önemi gittikçe artmaktadır. Sektördeki gelişime paralel olarak tüketicilerin karşılaştığı riskler farklılaşmakta ve satın alım sürecinde büyük sorunlar oluşturmaktadır. Bu çalışmanın amacı e-ticaret işlemlerinde tüketicilerin algıladığı riski ortaya koymaktır. Bu doğrultuda Konya ilindeki 230 katılımcıdan veriler elde edilmiş ve bu verilerin analizinde en küçük kareler yöntemi ile yapısal eşitlik modeli kullanılmıştır. Bu analiz sonuçlarına göre bütün boyutlar algılanan risk ana yapısıyla ilişki iken, tüketicilerin için en fazla riski oluşturan boyutlar benzer olmayan ürün, yetersiz hizmet ve işlem başarısızlığı olmuştur. Ayrıca, araştırmanın bulguları temelinde hem araştırmacılara hem de işletme yöneticilerine öneriler sunulmuştur.

Anahtar kelimeler: Algılanan Risk, E-ticaret, Yapısal Eşitlik Modeli

JEL Sınıflandırması: M30, M31

\section{Measuring the Risk Perceived by Consumers in Electronic Commerce Shopping: A Multidimensional Approach}

\begin{abstract}
With the impact of the Covid-19 outbreak, the importance of the electronic commerce (e-commerce) industry is increasing. In parallel to the development in the sector, the risks faced by the consumers differ and create major problems in the purchasing process. The purpose of this study is to reveal the risk perceived by consumers in ecommerce transactions. Accordingly, data were obtained from 230 participants in Konya province and the least squares method with structural equation model were used in the analysis of these data. According to the results of this analysis, while all dimensions are related to the main structure of perceived risk, the dimensions that pose the highest risk for consumers are dissimilar product, incapable service, and transaction failure. In addition, recommendations were made to both researchers and business managers on the basis of the research findings.
\end{abstract}

Keywords: Perceived Risk, E-commerce, Structural Equation Model

JEL Classification: M30, M31

\footnotetext{
${ }^{1}$ Karamanoğlu Mehmetbey Üniversitesi Bilimsel Araştırma ve Yayın Etik Kurulunun 17.12.2020 Tarih ve $\mathbf{2 7 5 1 9}$ Sayılı Etik Kurul onay kararı bulunmaktadır.

APA: Tuncer, İ. (2021). Elektronik Ticaret Alışverişinde Tüketicilerin Algıladığı Riskin Ölçümlenmesi: Çok Boyutlu Bir Yaklaşım. Bartın Üniversitesi İktisadi ve İdari Bilimler Fakültesi Dergisi, 12 (23), 96-111.

APA: Tuncer, İ. (2021). Measuring the Risk Perceived by Consumers in Electronic Commerce Shopping: A Multidimensional Approach. Bartın Unıversity Journal of Faculty of Economics and Admınıstratıve Sciences, 12 (23), 96-111.
} 


\section{Giriş}

İnternet, mobil cihazlar, lojistik altyapı, fiyat avantajı vb. parametrelerdeki değişim ve gelişimler tüketicilerin geleneksel ticaretten çevrimiçi ticarete geçişinde oldukça etkili olmuştur. Özellikle son dönemde covid-19 salgını ve sokağa çıkma kısıtlamalarının bu geçişi daha hızlandırdığını ifade edebiliriz. Örneğin, Türkiye'de ilk 6 aydaki toplam e-ticaret hacmi 2019'un ilk 6 ayına göre \%64 artış göstermiştir. Bu oranın oldukça büyük bir değişim olduğunu ifade edebiliriz. Dolaysıyla bu gelişim ve değişimin aslında tüketici davranışlarında da önemli bir değişim yaşandığını göstermektedir. Bunlardan en hızlı değişimi yaşayan alışkanlıklarımızdan biriside satın alma davranışlarının değişimidir. Değişen ve her gün ilerleyen bu alanda tüketicilerinde kara verme sırasında yaşadıkları zorluklar artmaktadır. Bu durumların başında gelen ise tüketicinin satın alma kararı sırasında öngöremediği durumlar nedeniyle karşı karşıya kaldıkları risklerdir. Özellikle son dönemde artan e-ticarete karşı dolandırıcılık, yanlış ürün gönderimi ve kredi kartı bilgilerinin çalınması gibi eylemler tüketicileri endişelendirerek algıladığı riski artırabilmektedir. $\mathrm{Bu}$ durum tüketicilerin e-ticaret üzerinden alışveriş davranışlarını olumsuz etkileyebilmektedir. Dolayısıyla tüketiciler satın alma sırasında karşı karşıya kaldıkları bu riskleri sıfıra indirgemeyi isterler (Roselius, 1971). Tüketicinin satın alma sırasında karşılaştığı belirsizliklere ise algılanan risk kavramı cevap bulmaktadır (Dholakia, 1997; Hussain vd., 2017; Stone ve Grønhaug, 1993). Ancak risk anlayışı kişiden kişiye değişebilen bir kavramdır (Mello ve Collins, 1998). Bu nedenle birçok çalışmada algılanan riskin boyutlarına dair farklı görüşler mevcuttur. Örneğin, literatürde Jacoby ve Kaplan (1972) ürün performans riski, fiziksel risk, finansal risk, sosyal risk ve psikolojik risk olarak beş boyuttan oluşan algılanan riski alt boyutlara ayırarak detaylı incelemiştir. Dahası, literatürde e-ticaret tüketicilerine yönelik yapılan risk araştırmalarında en fazla finansal, ürün performansı, psikolojik ve zaman kaybı boyutlarına odaklanıldığı tespit edilmiştir (Bashir vd., 2021). Bu tespit ne kadar tüketicilerin en fazla maruz kaldığı risk faktörlerinin bunlar olduğunu gösterse de aslında literatürde farklı boyutlara bilim insanları tarafından çok fazla odaklanılmadığına da işaret etmektedir. Ayrıca, e-ticaret sektöründeki parametrelerinde gelişim ve değişim birçok risk unsurunu beraberinde de getirebilmektedir. Ancak literatürdeki incelememizde çalışmalarda bu risk unsurlarına çok fazla odaklanılmadığını ifade edebiliriz. Dolayısıyla literatürde bu durum bir boşluk oluşturmaktadır. Literatürdeki bu boşluğu doldurmak için Bashir vd. (2021) çalışmalarında oldukça kapsamlı bir algılanan risk ölçeği geliştirmiştir. Ancak bu ölçeğin birçok araştırmada da irdelenip geçerliliğinin ve güvenirliliğinin güçlendirilmesi oldukça önemlidir. Dolayısıyla bu çalışmadaki verilerin farklı örneklem ve farklı kültür gibi faktörler nedeniyle analiz edilmesi literatüre önemli katkı sağlayacaktır.

$\mathrm{Bu}$ çalışma internet üzerinden alışveriş yapan müşterilerin algılanan risk algılarını farklı ve çok boyutlu bir araştırma modeliyle ölçümlemeyi amaçlamaktadır. Böylece tüketicilerin hangi boyutları daha riskli algıladığı ve hangi boyutları daha az riskli olarak algıladığı gibi sorulara cevap bulmuş olunacaktır. Bu çalışmanın 
bulgularının literatüre ve uygulayıcılara önemli katkılar sunması düşünülmektedir. Araştırma modeli temelinde düşündügümüzde, algılanan risk boyutları sektördeki güncel risk boyutlarını içermesi nedeniyle güncel risk sorunlarının çözümünde önemli ipuçları sağlayabilecektir. Bu modelin kullanıldığı çalışmalar sınırlıdır. Dolayısıyla mevcut modelin geçerliliği ve güvenirliliğinin güçlenmesine katkı sağlayabilecektir. Ayrıca taramamıza göre ulusal literatürde benzer çalışmanın olmadığı tespit edilmiştir. $\mathrm{Bu}$ durum ulusal literatürdeki boşluğun doldurulmasına ve zenginleşmesine de önemli katkılar sunacağı düşünülmektedir.

\section{Kavramsal Çerçeve}

\subsection{Algılanan Risk}

"Risk", bir karar vericinin hem alternatiflerin sonuçları hem de olası sonuçların ortaya çıkma olasılıkları hakkında önceden bilgi sahibi olduğu durum olarak tanımlanabilmektedir (Dowling, 1986). Ayrıca risk, insani değer taşıyan bir şeyin tehlikede olduğu ve sonucun belirsiz olduğu bir durum veya olay olarak da ifade edilmektedir (Rosa, 2003).

Algılanan risk ise Bauer (1960) tarafından; "tüketicilerin bir ürünü satın alırken karşılaştıkları belirsizlik olarak" tanımlanarak literatüre kazandırılmıştır (Desrochers ve François Outreville, 2020; Dholakia, 1997; Hussain vd., 2017; Stone ve Grønhaug, 1993). Literatürde algılanan risk kavramının yaygınlaşması ise Cunningham (1967) 'de yaptığı çalışma ile gerçekleşmiştir. Cunningham (1967), algılanan riski, bir olayın gerçekleşmesindeki algılanan kesinlik ve olayın gerçekleşmesi durumunda ortaya çıkan sonuç olarak iki boyuttan oluşan bir durum olarak tanımlamaktadır (akt. Hawes ve Lumpkin, 1986). Diğer yandan algılanan risk terimi, bireyin kararının potansiyel olarak olumsuz sonuçlarına ilişkin öznel inancı anlamına gelir (Quintal vd., 2010; Samadi ve Yaghoob-Nejadi, 2009; Tseng ve Wang, 2016).

Literatürde yapılmış ilk çalışmalarda algılanan riskin iki temel boyutundan biri belirsizlik ya da kayıp olasılığı kavramıyla, diğeri ise zarar kavramının sonucu ya da önemi ile ilgili olduğu bulunmuştur (Mello ve Collins, 1998). Ancak ilerleyen yıllarda yapılmış çalışmalarda ise algılanan risk boyutları ile ilgili farklı görüşler mevcuttur. Bunun nedeni çalışmaların alan farklılığından kaynaklandığı düşünülmektedir. Çalışmaların bir kısmı pazarlama veya çevrimiçi satın alma niyetleri bağlamında gerçekleştirilmiş olsa da birçok çalışma insan davranışları ve psikoloji alanında yürütülmüştür. Örneğin; Roselius (1971), algılanan risk boyutlarını; zaman kaybı, tehlike kaybı, ego kaybı ve para kaybı olarak bir tüketicinin bir satın alma kararı nedeniyle karşılaşabileceği olası kayıpları kategorize ederek açıklamıştır. Diğer yandan Jacoby ve Kaplan (1972) tüketicilerin algıladığı çeşitli risk boyutlarını ürün performans riski, fiziksel risk, finansal risk, sosyal risk ve psikolojik risk olarak tanımlamaktadır. Literatürdeki çevrimiçi alışveriş üzerine yapılan çalışmalarda algılanan risk boyutu olarak en fazla finansal risk, ürün performans riski, psikolojik risk ve zaman kaybı riski 
boyutları kullanılmıştır. Ayrıca teslimat riski, sosyal risk, mahremiyet riski ve güvenlik riski boyutları ortalama düzeyde kullanılırken, bilgi ve dolandırıcılık riskinin ise algılanan risk çalışmalarında daha az yer aldığı tespit edilmiştir (Bashir vd., 2021)

\section{Tablo 1: Algılanan Risk Boyutlarına İlişkin Tanımlar}

\begin{tabular}{|c|c|c|}
\hline Terim & Tanım & Araștırmacılar \\
\hline Fiziksel Risk & $\begin{array}{l}\text { Bireyin sağlığına zararlı ürünlerin } \\
\text { satılması durumunun oluşturduğu risktir. }\end{array}$ & $\begin{array}{l}\text { Roselius, } 1971 ; \\
\text { Jacoby ve Kaplan, } \\
1972\end{array}$ \\
\hline Sosyal Risk & $\begin{array}{l}\text { Diğer insanların algılarının bir bireyin } \\
\text { internet üzerinden satın alma davranışını } \\
\text { etkileme olasılığıdır. }\end{array}$ & $\begin{array}{l}\text { Jacoby ve Kaplan, } \\
\text { 1972; Lutz ve Reilly, } \\
\text { 1974; } \\
\text { Prasad, } 1975\end{array}$ \\
\hline Psikolojik Risk & $\begin{array}{l}\text { Bireyin duygusal strese maruz kalma } \\
\text { olasılığ1 olarak tanımlanır. }\end{array}$ & $\begin{array}{l}\text { Roselius, } 1971 ; \\
\text { Jacoby ve Kaplan, } \\
\text { 1972; Chen, } 2012\end{array}$ \\
\hline Finansal Risk & $\begin{array}{l}\text { Çevrimiçi alışverişten kaynaklanan parasal } \\
\text { kaybı temsil eder. }\end{array}$ & $\begin{array}{l}\text { Roselius, } 1971 ; \\
\text { Jacoby ve Kaplan, } \\
\text { 1972; Prasad, 1975; } \\
\text { Jarvenpaa ve Todd, } \\
\text { 1996; Chen, 2012 }\end{array}$ \\
\hline $\begin{array}{ll}\text { Zaman } & \text { Kayb1 } \\
\text { Riski } & \end{array}$ & 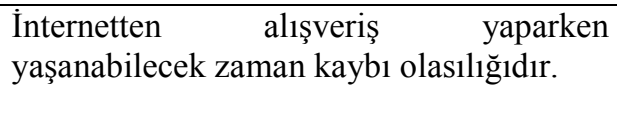 & $\begin{array}{ll}\text { Roselius, } & 1971 ; \\
\text { Zhang vd., } & \text { 2012; } \\
\text { Chen, 2012 }\end{array}$ \\
\hline $\begin{array}{l}\text { Ürün } \\
\text { Performans } \\
\text { Riski }\end{array}$ & $\begin{array}{l}\text { Tüketicinin satın aldığı ürünün beklediği } \\
\text { performansı sağlaması veya sadece kısa } \\
\text { bir süreliğine ürünün kullanılabilmesinin } \\
\text { olasılık riskidir. }\end{array}$ & $\begin{array}{l}\text { Jacoby ve Kaplan, } \\
\text { 1972; Lutz ve Reilly, } \\
\text { 1974; Chen, } 2012\end{array}$ \\
\hline $\begin{array}{l}\text { Güvenlik ve } \\
\text { Gizlilik Riski }\end{array}$ & $\begin{array}{l}\text { Tüketicinin finansal işlemler sırasında } \\
\text { kişisel bilgilerinin veya satın alma öncesi } \\
\text { ve sonrası davranış analiz raporlarının } \\
\text { kötü niyetli kişilere geçme riskidir. }\end{array}$ & $\begin{array}{l}\text { Jarvenpaa ve Todd, } \\
\text { 1996; Chen, } 2012\end{array}$ \\
\hline
\end{tabular}

Ekonomik (finansal) risk, tüketicinin satın alma karar sürecinin tüketicinin diğer satın alma işlemlerini etkileyebilmesi nedeniyle ekonomik bir öneme sahiptir. Dolayısıyla ekonomik risk düzeyi tüketicilerin gelir durumu ve alım gücü gibi faktörlerin durumuna göre değişkenlik gösterebilmektedir (Prasad, 1975). Psikolojik ve sosyal risk çalışmalarda çoğunlukla bütünleştirilerek tek boyut olarak ele alınmıştır. Psikolojik risk bireyin kendini nasıl algıladığına ilişkin durumları anlatırken (Jacoby ve Kaplan, 1972), sosyal risk ise tüketicinin satın alma davranışlarının başkaları tarafından ne derece etkilendiğiyle ilgili durumu açıklamaktadır (Prasad, 1975). Zaman riski tüketicinin satın almadan önce araştırma yapmak, alışveriş yapmak veya gönderilen istenmeyen ürünleri iade ya da değiştirmek zorunda kalmasından doğan zaman kaybı 
nedeniyle kötü bir satın alma kararı vermesine ilişkin potansiyel zaman kaybını anlatmaktadır (Zhang vd., 2012). Bunun yanında ürün performans riskinin algılandığı bazı durumlar mevcuttur. Örneğin, gri pazar malları olarak nitelendirilen internet üzerinden alışverişlerde tüketici ürünü doğrudan üreticiden veya yetkili bayiden alamadığı için garanti aracı firma tarafından sağlanmaktadır. Dolayısıyla bu durum tüketicinin ürün performansı riskini artırabilmektedir (Chen, 2012).

$\mathrm{Bu}$ çalışmada yukarıda ifade edilen algılanan risk boyutlarından farklı olarak bir model oluşturulmuştur. Çünkü gelişmiş e-ticaret sektöründe var olan boyutların tüketicilerin algılanan riskini tam anlamıyla ölçtüğünü ifade edemeyiz. Bu tezi literatürde yapılan çalışmaların odaklandığı boyutları incelendiğimizde gözlemleyebiliriz. Benzer boyutlar üzerine odaklanıldığı anlaşılmaktadır. Dolayısıyla bu çalışmada sunulan algılanan risk yapısına ait boyutların e-ticaret sektöründe birçok risk parametresini kapsadığını ifade edebiliriz. Böylelikle müşterilerin güncel risk algılarını tam anlamıyla anlayabiliriz. Bu çalışmada yüksek fiyat, aldatma, işlem başarısızlığı, benzer olmayan ürün, yetersiz hizmet, yasadışı ürün, izolasyon, huzursuzluk, hoşnutsuzluk, satın alma öncesi ve satın alma sonrası gecikme risk boyutları kapsamında algılanan risk modeli tasarlanmıştır. Bu model Şekil 1'de sunulmuştur. Bashir vd. (2021) ifade ettiğimiz boyutları aşağıdaki gibi tanımlamıştır;

Yüksek fiyat riski: E-ticaret platformundaki satıcıların ürünlerin fiyatlarını yüksek tutması, gerekli indirimlerin yapılmaması ve ekstra kargo ücretleri gibi parametreleri kapsayan parametrelerden oluşmaktadır. Müşteri bu parametreler çerçevesinde e-ticaret alışverişlerinde ekstra para kaybı endişesi yaşamakta ve bu müşterideki risk faktörünü artırabilir.

Aldatma riski: Çevrimiçi alışveriş sanal bir sistem olması nedeniyle kredi kartı bilgileri verilerek alışveriş gerçekleştirilebilmektedir. Dolayısıyla bu durum kredi kartı bilgilerinin çalınması, gizli ücret alınması ve satış sahtekarlığına neden olabilmektedir. E-ticaret platformu üzerinden müşterilerin yaptığı alışverişte bu durum endişeyi artırmakta ve dolayısıyla risk faktörü barındırmaktadır. Bu risk kapsamı aldatma riski olarak ifade edilmektedir.

İşlem başarısızlığ r riski: Bu risk türü genel olarak kişiden ve e-ticaret sitesinden kaynaklanmaktadır. Örneğin, yanlış ürün satın alımı, iade hizmetlerinin olmaması, hasarlı ürün ve ürün kaybı gibi eylemlerin oluşması işlem başarısızlığg riski kapsamına girmektedir.

Benzer olmayan ürün riski: Müşterilerin genel olarak en fazla endişe duyduğu risk boyutlarından biridir. E-ticaret platformundan sergilenen ürünün rengi, boyutu ve işlevinin müşteriye teslim edilen ürünle benzer olmama ihtimali müşteri endişelendirmekte ve risk algısı oluşturmaktadır. 
Yetersiz hizmet riski: E-ticaret platformundaki satıcının satın alma öncesi ve sonrası müşterilerin isteklerini karşılayamama ile ilgili endişelerden oluşmaktadır. Özellikle sağlam bir e-ticaret altyapısı olmayışından kaynaklanmaktadır.

Yasadışı ürün riski: Müşterinin e-ticaret platformunda satılan ürünün orijinalliğine karşı duyduğu endişe olarak ifade edilmektedir.

İzolasyon risk: E-ticaret sitesinden alınan ürün sonrası müşteride yaşanan duyma endişesi olarak ifade edilebilir.

Huzursuzluk riski: Müşterinin e-ticaret alışverişinde yaşayabileceği kötü deneyim, psikolojik rahatsızlıklar ve gereksiz gerginliklerle ilgili endişelerden oluşmaktadır.

Hoşnutsuzluk riski: E-ticaret davranışıyla ilgili müşteride oluşan pişmanlık ve alışveriş hedeflerine ulaşamamanın verdiği gerginliklerin oluşturduğu durum olarak ifade edilmektedir.

Satın alma öncesi gecikme riski: Müşterinin satın alma sürecinde e-platform temelli yaşadığı aksaklıklardan dolayı e-alışveriş eyleminin çok uzun sürme endişesi olarak ifade edilmiştir.

Satın alma sonrası gecikme riski: E-alışveriş sonrası yaşanan süreçte gecikme endişesi olarak açıklanmıştır. Örneğin, ürünün kargoda kaybolması veya zamanında ulaşmamasıdır.

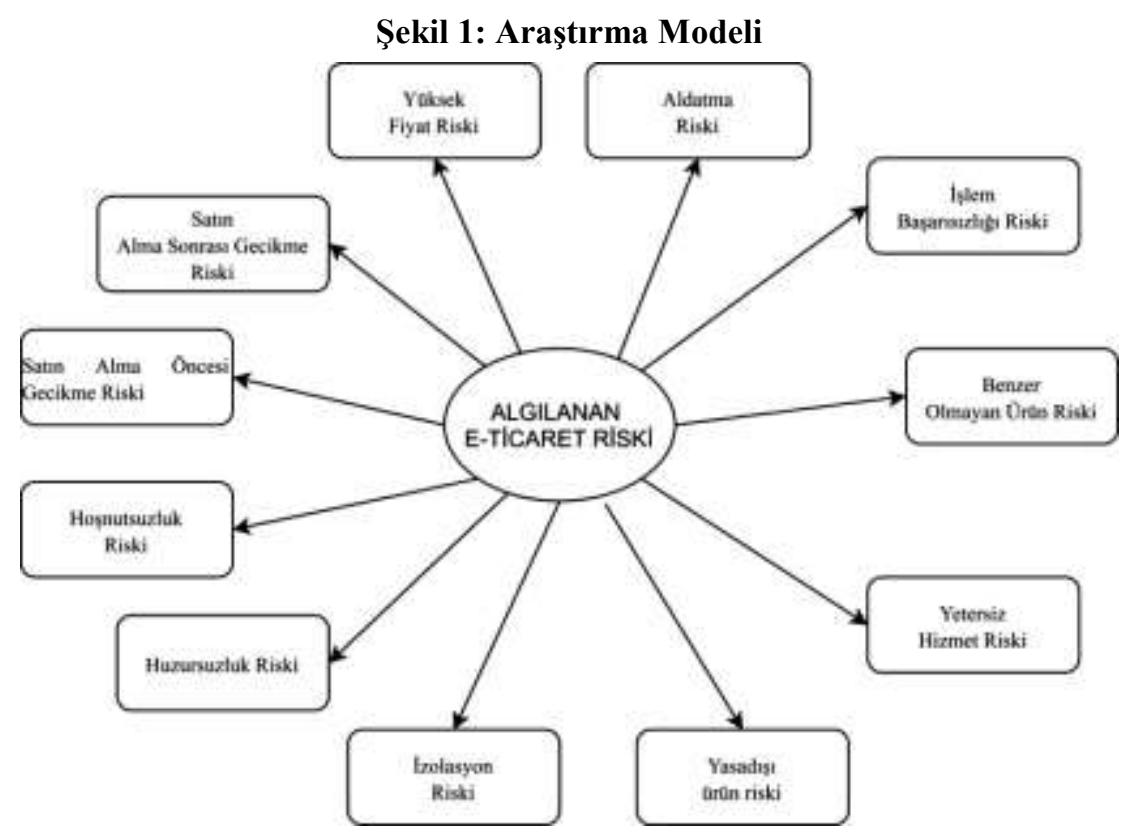


Roselius (1971) göre tüketici algıladığı riski minimum düzeyde tutmak için dört farklı strateji izleyebilmektedir. (1) tüketici satın alma işlemlerini sekteye uğratacak tehditleri asgari düzeyde tutarak satın alma başarısızlığı ihtimalini azaltabilir veya eğer satın alma işlemi başarısız olmuşsa bunun kendisinde oluşturacağı hasar kaybı düzeyini en aza indirerek algılanan risk düzeyini asgari düzeyde tutabilir. (2) satın alma işlemi sonrası yaşanabilecek kayıp türlerinde değişiklik yaparak tolerans düzeyini artırabilir. (3) satın alma işlemini öteleyebilir veya (4) sorumluluk alarak tahmin edilemeyen riskleri bulunan satın alma işlemi gerçekleştirebilir. Diğer yandan "göze çarpan" tüketicilerin tavsiyeleri satın alma riskini en aza indirgemek ve satın alma davranışına motive olmak için yeterli sayılabilir. Göze çarpan tüketiciler, işlevsel olmayan ihtiyaçları yüksek olan ve daha önce satın alış tecrübeli kişiler olarak tanımlanmıştır (Bhatnagar \& Ghose, 2004).

Genel olarak algılanan riskin birkaç bağımsız risk çeşidinden oluştuğunu ileri sürmek yanlış olmayacaktır. Yani bazı risk unsurları artarken bazıları azalabilmektedir. $\mathrm{Bu}$ nedenle çoğu zaman tüketici risk (değiş-tokuş) davranışını sergileyecektir. Tüketici aldığı bu risk eyleminde kendi algısında bir denge oluşturmaktadır. Örneğin, tüketicinin estetik fayda sağlamak için satın alma davranışı gerçekleştirdiği beyazlatıcı diş macunu fiziksel riski artırırken sosyal risk azaltabilmektedir (Jacoby ve Kaplan, 1972). Dolayısıyla bu noktada tüketicinin algıladığı risk dengesi satın alma işleminde ana unsuru oluşturmaktadır. İnternet üzerinden alışveriş davranışını inceleyen çalışmalarda da algılanan risk boyutlarından sosyal risk, ekonomik risk ve güvenlik risklerinin tüketiciyi satın alma davranışını yönlendirdiği bulgusuna ulaşılmıştır (Zhang vd., 2012).

Birçok durumda tüketici daha önce hedeflediği ürünle ilgili bir alışveriş deneyimi yaşamadığı için risk faktörlerini değerlendirirken nesnel bir yaklaşım sergileyebilmesi oldukça zordur. $\mathrm{Bu}$ durum tüketicinin satın alma motivasyonun da satıcı ile ilgili öznel değerlendirmelerin belirleyici olduğu ifade edilebilir (Mello ve Collins, 1998). Dolayısıyla marka sadakati, satıcı güveni, tazminat garantisi ve iade koşulları gibi faktörler tüketicinin riskleri sıfıra indirme çabası ve kayıp yaşamayı önleme gibi eylemlerine katkı sağlayarak tüketicinin satın alma ile ilgili öznel yaklaşımlarını pozitif yönde etkileyecektir (Lutz ve Reilly, 1974; Roselius, 1971). Bu noktadan hareketle, satıcıların iade politikası gibi risk algısını azaltıcı pazarlama iletişim faaliyetleri yürütmesi tüketicilerin satın alma karar süreçlerine önemli katk1 sağlayabilmektedir. Dahası, satıcının ürün riski algısı yüksek müşterilere yönelik tüketicilerin deneyim sağlayabileceği showroom gibi ortamlar oluşturması tüketicilerin güvenini artırabilmektedir (Bhatnagar ve Ghose, 2004).

\section{Metodoloji}

$\mathrm{Bu}$ çalışmada elektronik ticaret yoluyla yapılan alışverişlerde tüketicilerin algıladığı risklerin çok boyutlu bir değişken temelinde ölçümlenmesi amaçlanmıştır. Bu amacı gerçekleştirmek için literatürde daha önce kullanılmış ve güvenirliği sağlanmış ölçeklerden yararlanılmıştır. Tüketicilerin algıladıkları riski ölçümlemek için Bashir vd. 
(2021) geliştirdiği çok boyutlu ölçekten yararlanılmıştır. Ölçekte cevaplar 5'li likert tipi derecelendirme olarak uygulanmıştır ( 1: Kesinlikle katılmıyorum,.....,5: Kesinlikle katılıyorum). Bu çalışmanın evrenini Türkiye'deki 18 yaş üstü e-ticaret kullanıcıları oluşturmaktadır. Ancak ulaşılabilir evren olarak Konya ili tercih edilmiştir. İlk olarak pilot çalışma ile yüz geçerlilik testi yapılmış ve veriler analiz edilmiştir. Veriler Aralık 2020 - Ocak 2021 tarihleri arasında anket yöntemi kullanılarak elde edilmiştir. Ayrıca, anket uygulanmadan önce Karamanoğlu Mehmetbey Üniversitesi Bilimsel Araştırma ve Yayın Etik Kurulunun 17.12.2020 tarih ve 27519 sayılı etik kurul onayı alınmıştır. Anket sosyal medya araçları ile paylaşılarak internet üzerinden uygulanmıştır. Örneklem metodu olarak kolayda örnekleme yöntemi tercih edilmiştir. Uygulanan anket neticesinde 245 katılımcıya ulaşılmıştır. Bazı soruların bilinçli olarak cevaplanmadığ tespit edilmesi nedeniyle veriden çıkartılmıştır. Analiz için kullanılabilir veri 230 olarak gerçekleştirmiştir. Evren net olarak bilinmemesi nedeniyle bir eşik değer bulunmamaktadır. Ancak bu çalışmada verilerin analizinde en küçük kareler yöntemi ile yapısal eşitlik modeli uygulanması nedeniyle elde edilen sayının yeterli olduğunu ifade edebilir. Çünkü bu yöntem ile küçük örneklemler ile de verimli sonuçlar alınabilmektedir (Ali vd., 2018). Literatürde daha önce yapılmış çalışmalar (Lal, 2017; Naranjo-Zolotov vd., 2021; Ng, 2013) bu durumu destekler niteliktedir.

Yukarıda da ifade ettiğimiz üzere bu çalışmada verilerin analizinde en küçük kareler yöntemi ile yapısal eşitlik modellemesi kullanılmıştır. $\mathrm{Bu}$ analiz yönteminin birçok avantajı bulunması bu yöntemin kullanılmasında belirleyici olmuştur. Kısmi en küçük kareler yapısal eşitlik modellemesi (PLS-SEM), kovaryans temelli yapısal eşitlik modellemesine kıyasla ölçüm modeli (rekleftif ve formatif), örneklem büyüklüğü ve artık dağılımlar açısından minimum talepte bulunması nedeniyle araştırma modelini incelemek için en uygun teknik olarak görülmüştür (Sarstedt ve Cheah, 2019). Ayrıca, PLS-SEM karmaşık modelleri değerlendirmede en iyi performansı gösterdiği tespit edilmiştir (Sarstedt vd., 2019). Bu çalışmada yapılar arası bir ilişki incelenmediği için sadece doğrulayıcı faktör analizi uygulanacaktır. Diğer bir deyişle, ölçüm modeline ilişkin değerler analize dahil edilecektir.

\section{Bulgular}

\subsection{Tanımlayıcı İstatistik Bulguları}

Araştırma ölçeğindeki ifadeler ve her bir ifadeye verilen ortalama değerler Tablo 2 'de sunulmuştur. Her bir ifadeye ilişkin ortalama değerler ise 2.4 ile 4.0 aralığında değişmektedir. Katılımcıların \% 45'i kadın ve \% 55'i erkeklerden oluşmaktadır. Yaş temelinde katılımcıların \% 25'i 18-20 yaş, \% 37'si 25-34 yaş, \% 23'ü 35-44 yaş, \% 9'u 45-54 yaş ve \% 6'sı 55-64 yaş aralığında bulunmaktadır. Diğer taraftan katılımcılardan hangi sıklıkla alışveriş yaptığı bilgisi istenmiştir. Katılımcıların yaklaşık \%40'1 ayda en az bir kez alışveriş, yaklaşık \% 9'u haftada en az bir kez alışveriş, yaklaşık \% 21'i üç 
ayda en az bir kez alışveriş, yaklaşık \% 11 'i altı ayda en az bir kez alışveriş ve yaklaşık \% 19'u altı ayda en fazla bir kez alışveriş yaptığını ifade etmiştir.

\section{Tablo 2: Algılanan Risk Ölçeği, Ortalama ve Faktör Yükü Değerleri}

\begin{tabular}{|c|c|c|c|}
\hline Boyutlar & İfadeler & $\mathbf{F}$ & $\mathbf{O}$ \\
\hline \multirow{4}{*}{$\begin{array}{l}\text { Yüksek } \\
\text { Fiyat } \\
\text { Riski }\end{array}$} & $\begin{array}{l}\text { İnternetten alışveriş yaparken satıcıların yüksek satış fiyatı belirlemesi } \\
\text { nedeniyle ürünü pahalı almış olabilirim. }\end{array}$ & 0.78 & $\overline{3,0}$ \\
\hline & $\begin{array}{l}\text { İnternetten alışveriş yaparken satıcının sunduğu düşük oranlı indirimler } \\
\text { nedeniyle ürünü pahalı almış olabilirim. }\end{array}$ & 0.79 & 3,1 \\
\hline & $\begin{array}{l}\text { İnternetten alısveriş yaparken, üçüncü ödeme taraflarının talep ettiği } \\
\text { yüksek işlem ücreti nedeniyle fazla ücret ödemiş olabilirim. }\end{array}$ & 0.75 & 2,6 \\
\hline & $\begin{array}{l}\text { İnternetten alışveriş yaparken kargo firmasının talep ettiği yüksek kargo } \\
\text { ücreti nedeniyle fazla ücret ödemiş olabilirim. }\end{array}$ & 0.67 & 3,0 \\
\hline \multirow{3}{*}{$\begin{array}{l}\text { Aldatma } \\
\text { Riski }\end{array}$} & İnternetten alıșveriş yaparken satıcı kredi kartı numaramı çalabilir. & 0,83 & 3,5 \\
\hline & İnternetten alışveriş yaparken satıcı benden gizli bir ücret alabilir. & 0,75 & 2,6 \\
\hline & İnternetten alışveriș yaparken satıcı sahtekarlık yapabilir. & 0,73 & 3,6 \\
\hline \multirow{4}{*}{$\begin{array}{l}\text { İşlem } \\
\text { Başarısızılı } \\
\text { ğı Riski }\end{array}$} & İnternetten aldığım ürün kargoda kaybolabilir. & 0.75 & 3,2 \\
\hline & $\begin{array}{l}\text { İnternet alşsverişinde kargoda zarar görmüş bir ürün teslim aldığım } \\
\text { olmuştur. }\end{array}$ & 0.64 & 3,4 \\
\hline & İnternetten alışveriş yaparken yanlış bir ürün alabilirim. & 0.63 & 3,1 \\
\hline & $\begin{array}{l}\text { İnternetten alışverişimde ödeme iadesi durumunda paramı geri } \\
\text { alamayabilirim. }\end{array}$ & 0.77 & 3,3 \\
\hline \multirow{4}{*}{$\begin{array}{l}\text { Benzer } \\
\text { Olmayan } \\
\text { Ürün } \\
\text { Riski }\end{array}$} & $\begin{array}{l}\text { İnternetten satın alınan ürünün görünümü, gösterilen resimden farklı } \\
\text { olabilir. }\end{array}$ & 0.85 & 4,0 \\
\hline & $\begin{array}{l}\text { İnternet mağazasından satın alınan ürünün boyutu, reklamlarda } \\
\text { gördüğümden farklı olabilir. }\end{array}$ & 0.81 & 4,0 \\
\hline & $\begin{array}{l}\text { İnternetten mağazasından satın alınan ürünün rengi reklamı verilenden } \\
\text { farklı olabilir. }\end{array}$ & 0.86 & 3,9 \\
\hline & $\begin{array}{l}\text { İnternetten satın alınan ürünün işlevi, reklamlarda gördüğümden farklı } \\
\text { olabilir. }\end{array}$ & 0.80 & 3,8 \\
\hline \multirow{3}{*}{$\begin{array}{l}\text { Yetersiz } \\
\text { Hizmet } \\
\text { Riski }\end{array}$} & $\begin{array}{l}\text { İnternetten satın aldığım ürün, satın alırken rahatllğını hissedemediğim } \\
\text { için beni tatmin etmeyebilir. }\end{array}$ & 0.80 & 3,7 \\
\hline & $\begin{array}{l}\text { İnternetten satın aldığım ürün, satın alırken dokunamadığım için beni } \\
\text { tatmin etmeyebilir. }\end{array}$ & 0.75 & 3,8 \\
\hline & $\begin{array}{l}\text { İnternetten satın alınan ürün, satıcı ürünü rahatlıkla iade etmeme izin } \\
\text { vermeyebileceği için beni tatmin etmeyebilir. }\end{array}$ & 0.87 & 3,5 \\
\hline \multirow[t]{3}{*}{$\begin{array}{l}\text { Yasadışı } \\
\text { ürün riski }\end{array}$} & $\begin{array}{l}\text { İnternetten mağazasından satın alınan ürünün kalitesi, satıcının reklamını } \\
\text { yaptığından daha düşük olabilir. }\end{array}$ & 0.86 & 3,9 \\
\hline & $\begin{array}{l}\text { İnternet mağazasından satın aldığım ürün sahte bir marka olabilir. (ör. } \\
\text { orijinal marka olduğu iddia edilirken bir kopya satılır vb.). }\end{array}$ & 0.90 & 3,9 \\
\hline & $\begin{array}{l}\text { İnternet mağazasından satın aldığım ürün hakkında yapılan yorumlar } \\
\text { belirli bir internet satıcısı ile ilgili gerçeği yansıtmayabilir }\end{array}$ & 0.80 & 3,6 \\
\hline \multirow{3}{*}{$\begin{array}{l}\text { İzolasyon } \\
\text { Riski }\end{array}$} & İnternet mağazasından satın aldığım ürün sosyal imajıma uymayabilir. & 0.87 & 3,1 \\
\hline & $\begin{array}{l}\text { İnternet mağazasından satın aldığım ürün, ailemin ve arkadaşlarımın } \\
\text { önünde beni utandırabilir. }\end{array}$ & 0.70 & 2,5 \\
\hline & $\begin{array}{l}\text { İnternetten alışveriş yaparken kişisel verilerimin çalınması beni } \\
\text { utandırabilir. }\end{array}$ & 0.83 & 3,4 \\
\hline $\begin{array}{l}\text { Huzursuzl } \\
\text { uk Riski }\end{array}$ & $\begin{array}{l}\text { Geçmişte internet alışveriş deneyimim hoş olmayan şekilde sonuçlandı. } \\
\text { (örneğin, sahte web sitesinden anlaşma yapmaktan veya sahte uygulama } \\
\text { kullanmaktan dolayı). } \\
\text { İnternetten satın alma işlemi gerçekleştirirken (ör. Kimlik avı } \\
\text { dolandırıcllığ nedeniyle) psikolojik olarak rahatsız oluyorum. } \\
\text { İnternetten hir satın alma islemini gerceklestirirken (örneờin özel kötï }\end{array}$ & 0.64 & 2,5 \\
\hline
\end{tabular}




\begin{tabular}{|c|c|c|c|}
\hline & & \multirow[b]{2}{*}{0.77} & \multirow[b]{2}{*}{2,4} \\
\hline & $\begin{array}{l}\text { amaçlı yazılımlar nedeniyle) gereksiz gerginlik hissediyorum. } \\
\text { İnternetten satın aldığım bir ürün ödemesi gerçekleştirirken ruhsal olarak } \\
\text { huzursuz olurum. (ör. Depresyon, hastalık vb.) }\end{array}$ & & \\
\hline \multirow[t]{3}{*}{$\begin{array}{l}\text { Hoşnutsuz } \\
\text { luk Riski }\end{array}$} & $\begin{array}{l}\text { İnternetten alışveriş yaparken, ürünün özelliğine ilişkin taleplerimin } \\
\text { reddedilmesi internet mağazasından memnun olmamama neden olur. }\end{array}$ & 0.70 & 3,7 \\
\hline & $\begin{array}{l}\text { İnternetten alışveriş yaparken, kalitesi düşük bir ürün satan mağazadan } \\
\text { alışveriş yapmaktan memnun olmam. }\end{array}$ & 0.63 & 4,1 \\
\hline & $\begin{array}{l}\text { Satın alma hedeflerime ulaşamamanın verdiği rahatsızlık, internetten } \\
\text { alışveriş memnuniyetsizliğimi artırır. }\end{array}$ & 0.81 & 3,9 \\
\hline $\begin{array}{l}\text { Satın } \\
\text { Alma }\end{array}$ & $\begin{array}{l}\text { Uygun alışveriş sitesi aramak zamanımın boşa harcanmasına neden } \\
\text { olabilir. }\end{array}$ & 0.88 & 3,5 \\
\hline $\begin{array}{l}\text { Öncesi } \\
\text { Gecikme }\end{array}$ & $\begin{array}{l}\text { İnternet satışı yapanlarla iletişim kurmaya çalışmak zamanımım boşa } \\
\text { harcanmasına neden olabilir. }\end{array}$ & 0.90 & 3,4 \\
\hline \multirow[t]{2}{*}{ Riski } & $\begin{array}{l}\text { İnternet mağazasının ödeme prosedürleri zamanımın boşa harcanmasına } \\
\text { neden olabilir. }\end{array}$ & 0.77 & 2,9 \\
\hline & $\begin{array}{l}\text { İnternetten alışveriş yaparken, sistem dalgalanmaları (örneğin yavaş } \\
\text { internet) zamanımı boşa harcayabilir. }\end{array}$ & 0.79 & 3,4 \\
\hline Satın & İnternet mağazasından satın alınan ürün zamanında teslim edilmeyebilir. & 0.68 & 3,9 \\
\hline $\begin{array}{l}\text { Alma } \\
\text { Sonrası }\end{array}$ & $\begin{array}{l}\text { İnternet mağazasının iade prosedürü zamanımın boşa harcanmasına } \\
\text { neden olabilir. }\end{array}$ & 0.81 & 3,8 \\
\hline $\begin{array}{l}\text { Gecikme } \\
\text { Riski }\end{array}$ & $\begin{array}{l}\text { İnternet mağazasının sipariş iptal prosedürü zamanımın boşa } \\
\text { harcanmasına neden olabilir. }\end{array}$ & 0.88 & 3,6 \\
\hline
\end{tabular}

\section{2. Ölçüm Modeli}

$\mathrm{Bu}$ aşamada bu çalışmada kullanılan ölçeğin kısmı en küçük kareler yapısal eşitlik modellemesi ile güvenirliği ve geçerliliği test edilmiştir. Ölçeğin güvenirliliği ile ilgili cronbach $\alpha$ (CA), Dijkstra-Henseler'in rho $(\rho A)$ ve bileşik güvenilirlik (CR) değerleri kontrol edilerek doğrulanmaktadır. Bu değerlerin her biri 0.70 üzerinde olmas1 gerekmektedir (Hair vd., 2019) Tablo 3'deki değerlen incelendiğinde her bir boyuta ilişkin CA, $\rho \mathrm{A}$ ve $\mathrm{CR}$ değerlerinin eşik değer üzerinde olduğu anlaşılmaktadır. Dolayısıyla ölçeğin güvenilirliği sağlanmıştır. Ölçek güvenirliği sağlandıktan sonra modele ilişkin yakınsama geçerliliği test edilmiştir. Bu test için açıklanan ortalama varyans (AVE) ve faktör yükü değerleri incelenmiştir. Bu değerlerin 0.5 üzerinde olmas1 gerekmektedir (Bagozzi vd., 1991; Fornell ve Larcker, 1981). Tablo 2'deki bu değerler incelendiğinde ise her bir faktörün değeri ve AVE değerlerinin (Tablo 3) referans değer üzerinde olduğu gözlemlenmektedir. Dolayısıyla araştırma modelinin yakınsak geçerliliği sağlanmıştır. Son olarak ise ayrışma geçerliliği test edilmiştir. Bu test için ise araştırmada heterotrait-monotrait (HTMT) korelasyon oranı ve FornellLarcker kriteri kullanılmıştır. HTMT' ye göre her bir heterotrait-monotrait korelasyonları arasındaki oranın değeri 0.90 'ın altında değer alması gerekmektedir (Henseler vd., 2015). Fornell-Larcker kriterinde ise her bir AVE'nin karekökünün değişkenler arası korelasyon değerlerinden düşük olması gerekmektedir. Tablo 3 'teki HTMT ve Fornell-Larcker kriterleri değerlendirdiğinde araştırma modelimizin ayrışma geçerliliğinin sağlandığı anlaşılmaktadır. 
Tablo 3: Güvenirlik ve Geçerlilik Değerleri

\begin{tabular}{|c|c|c|c|c|c|c|c|c|c|c|c|}
\hline Boyut & $\mathrm{AR}$ & $\mathrm{BO}$ & $\mathrm{HR}$ & HUR & SSG & SOG & $\mathrm{YU}$ & $\overline{\mathrm{YH}}$ & YK & ISR & IZO \\
\hline \multicolumn{12}{|c|}{ Fornell-Larcker kriteri } \\
\hline $\mathrm{AR}$ & 0,77 & & & & & & & & & & \\
\hline BO & 0,61 & $\mathbf{0 , 8 3}$ & & & & & & & & & \\
\hline HR & 0,22 & 0,36 & 0,71 & & & & & & & & \\
\hline HUR & 0,46 & 0,42 & 0,35 & 0,77 & & & & & & & \\
\hline SSG & 0,35 & 0,52 & 0,44 & 0,45 & 0,79 & & & & & & \\
\hline SOG & 0,36 & 0,37 & 0,41 & 0,58 & 0,56 & 0,84 & & & & & \\
\hline YU & 0,59 & 0,76 & 0,35 & 0,36 & 0,57 & 0,47 & $\mathbf{0 , 8 5}$ & & & & \\
\hline YH & 0,49 & 0,69 & 0,42 & 0,54 & 0,63 & 0,58 & 0,64 & $\mathbf{0 , 8 1}$ & & & \\
\hline YK & 0,62 & 0,42 & 0,17 & 0,37 & 0,35 & 0,41 & 0,44 & 0,38 & 0,75 & & \\
\hline ISR & 0,65 & 0,73 & 0,36 & 0,37 & 0,45 & 0,44 & 0,67 & 0,59 & 0,44 & 0,71 & \\
\hline IZO & 0,60 & 0,49 & 0,26 & 0,64 & 0,45 & 0,60 & 0,53 & 0,57 & 0,43 & 0,47 & $\mathbf{0 , 8 0}$ \\
\hline
\end{tabular}

\section{HTMT Değerleri}

AR

BO $\quad 0,82$

HR $\quad 0,39 \quad 0,54$

HUR $\quad 0,64 \quad 0,50 \quad 0,54$

SSG $\quad 0,52 \quad 0,68 \quad 0,75 \quad 0,59$

SOG $\quad 0,48 \quad 0,43 \quad 0,62 \quad 0,70 \quad 0,73$

YU $\quad 0,81 \quad 0,90 \quad 0,56 \quad 0,43 \quad 0,76 \quad 0,56$

$\begin{array}{llllllll}\text { YH } & 0,69 & 0,87 & 0,68 & 0,72 & 0,87 & 0,74 & 0,81\end{array}$

$\begin{array}{lllllllll}\text { YK } & 0,88 & 0,52 & 0,32 & 0,50 & 0,49 & 0,51 & 0,57 & 0,51\end{array}$

$\begin{array}{llllllllll}\text { ISR } & 0,87 & 0,86 & 0,61 & 0,52 & 0,66 & 0,57 & 0,89 & 0,82 & 0,62\end{array}$

\begin{tabular}{llllllllllll} 
IZO & 0,85 & 0,61 & 0,49 & 0,85 & 0,63 & 0,73 & 0,66 & 0,76 & 0,57 & 0,66 & \\
\hline CA & 0,66 & 0,85 & 0,52 & 0,78 & 0,71 & 0,86 & 0,82 & 0,74 & 0,75 & 0,67 & 0,74
\end{tabular}

$\begin{array}{llllllllllll}\mathbf{C R} & 0,67 & 0,86 & 0,54 & 0,81 & 0,72 & 0,87 & 0,83 & 0,76 & 0,75 & 0,69 & 0,77\end{array}$

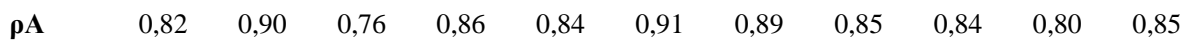

$\begin{array}{llllllllllll}\text { AVE } & 0,60 & 0,69 & 0,51 & 0,61 & 0,64 & 0,71 & 0,74 & 0,66 & 0,57 & 0,51 & 0,65\end{array}$

Not: AR= Aldatma Riski, BO= Benzer Olmayan Ürün Riski, HR= Hoşnutsuzluk Riski, HUR= Huzursuzluk Riski, SSG= Satın Alma Sonrası Gecikme Riski, SOG= Satın Alma Öncesi Gecikme Riski, YU= Yasadışı ürün riski, YH= Yetersiz Hizmet Riski, YK= Yüksek Fiyat Riski, ISR: İşlem Başarısızlığı Riski, IZO= İzolasyon Riski

Ayrıca bu bölümde algılanan risk yapısı ile boyutları arasındaki ilişkiyi test etmek için ikinci düzey doğrulayıcı faktör analizi yapılmıştır. Bu değerler ilişkin beta $(\beta)$, t-değerleri ve P-değerleri Tablo 4'te sunulmuştur. 


\section{Tablo 4: İkinci Düzey Doğrulayıcı Faktör Analizi}

\begin{tabular}{|l|c|c|c|}
\hline Boyut ve yapı arası ilişki & $(\boldsymbol{\beta})$ & T-değeri & $\begin{array}{c}\text { P- } \\
\text { değeri }\end{array}$ \\
\hline Aldatma Riski -> algılanan risk & 0,104 & 9,141 & 0,000 \\
\hline Benzer Olmayan Ürün Riski -> algılanan risk & 0,173 & 13,888 & 0,000 \\
\hline Hoşnutsuzluk Riski -> algılanan risk & 0,062 & 4,196 & 0,000 \\
\hline Huzursuzluk Riski -> algılanan risk & 0,129 & 9,621 & 0,000 \\
\hline Satın Alma Sonrası Zaman Gecikme Riski -> algılanan risk & 0,106 & 9,875 & 0,000 \\
\hline Satın Alma Öncesi Gecikme Riski -> algılanan risk & 0,158 & 11,651 & 0,000 \\
\hline Yasadıșı̈ Ürün Riski -> algılanan risk & 0,139 & 12,652 & 0,000 \\
\hline Yetersiz Hizmet Riski -> algıllanan risk & 0,127 & 13,203 & 0,000 \\
\hline Yüksek Fiyat -> algılanan risk & 0,110 & 7,263 & 0,000 \\
\hline İșlem Başarısızlı̆̆ı riski -> algılanan risk & 0,123 & 12,815 & 0,000 \\
\hline İzolasyon Riski -> algılanan risk & 0,115 & 10,896 & 0,000 \\
\hline
\end{tabular}

Tablo 4'deki değerleri incelediğimizde her bir alt boyutun ana yap1 olan algılanan risk yapısı ile ilişkili olduğu anlaşılmaktadır. Algılanan risk üzerinde en fazla etkili olan boyutlar benzer olmayan ürün riski, yetersiz hizmet riski ve işlem başarısızlığı riskidir. Daha az etkili olan boyutlar ise hoşnutsuzluk riski, yüksek fiyat riski ve aldatma riskidir.

\section{Tartışma ve Sonuç}

$\mathrm{Bu}$ çalışmada e-ticaret tüketicilerinin algıladığı risklerin çok boyutlu bir yapıyla ölçümlenmesi amaçlanmıştır. Literatürde özellikle e-ticaretin çoğu sürecini kapsayan çok boyutlu risk ölçeğinin eksikliği dikkat çekmektedir. Literatürdeki bu boşluğa katkı sunan çalışmaların varlığı oldukça sınırlıdır. Dolayısıyla çalışmanın bulguları literatürdeki bu boşluğa oldukça önemli katkılar sunmaktadır.

$\mathrm{Bu}$ çalışmanın bulgularına göre tüketicilerin algıladığı riski en fazla etkileyen boyutların benzer olmayan ürün riski, yetersiz hizmet riski ve işlem başarısızlığ 1 riskidir. Bu müşterilerin e-ticaret alışverişlerinde orijinal ürün tedirginliği ve satın alma sürecinde kaliteli hizmet almadıklarını göstermektedir. Katılımcıların bu boyutların ifadelerine verdiği cevapların ortalama değerleri de bu durumu destekler niteliktedir. Diğer taraftan, müşteriler genel olarak yüksek fiyat riskine karşı risk düzeyi daha düşüktür. Bu durum e-ticaretin avantajından kaynaklanabilir. Çünkü e-ticaret sitelerinin en büyük avantajı aynı ürünün fiyatlarını karşılaştırabilme imkanı sunmaktadır. Fiziksel mağazalarda yüksek fiyat riski daha fazla ön plana çıkabilmektedir. Çünkü karşılaştırma imkanı biraz kısıtlıdır. Benzer şekilde aldatma riski de müşterilere tarafından daha az riskli olarak algılanmıştır. Bu müşterilerin platformlara olan güvenini göstermektedir. Geçmişe göre günümüzde dijital platformlarının bu algıda etkisi olabilir. Günümüzde 
birçok markalaşmış e-ticaret platformları ortaya çıkmıştır. Dolayısıyla bu gelişmeler müşterilerin risk algısının azaltılmasında etkili olmuş olabilir. Hoşnutsuz riskinin müşteriler tarafından düşük riskli olması da benzer sebeplere dayanmaktadır. Çünkü gelişen e-ticaret pazarıyla rekabet üst düzeye çıktı ve birçok platform kaliteli ürünler ve hizmetler sunarak rekabet sağlamaktadır.

$\mathrm{Bu}$ çalışmanın bulguları literatüre birtakım katkılar sunmaktadır. İlk olarak, literatür incelendiğinde birçok çalışmanın kısıtlı boyutlar çerçevesinde temel e-ticaret risk boyutlarına değindiği gözlemlenmiştir. Bu çalışmada birçok risk boyutunu dikkate alarak bir model oluşturmuş ve e-ticaret riskinin uçtan uca değerlendirilmesine katkı sunmuştur. İkinci olarak, daha önce benzer bir model kullanılmasına rağmen hangi boyutun algılanan risk üzerinde ne kadar etkin olduğuna değinilmemiştir. Bu çalışmada her bir algılanan risk boyutunun ana değişken üzerinde etkinliği analiz edilmiştir. Son olarak ise bu çalışma ile mevcut ölçeğin bulguları güçlendirilerek daha fazla geçerlilik ve güvenirliğinin olmasına katkı sunmuştur.

$\mathrm{Bu}$ çalışmanın bulguları uygulayıcılara ve yöneticilere bir takım öneriler sunmaktadır. $\mathrm{Bu}$ çalışmanın bulgularına göre müşteriler tarafından en fazla riskli algılanan boyutlar benzer olmayan ürün, yetersiz hizmet ve işlem başarısızlığıdır. Dolayısıyla işletmeler görseldeki ürün ile müşterinin elde ettiği ürünün aynı algılanması için çeşitli teknolojilerden yararlanması bu riski azaltabilir. Örneğin, ürünle ilgili video içeriklerin paylaşılması bu riski azaltacaktır. Çünkü video içeriğindeki ürün fotoğraftaki ürüne göre daha fazla gerçeği yansıtabilir. Diğer taraftan, e-ticaret işletmelerinin aldatıcı içerikler sunması da bu risk artırabilmektedir. Bu kısa vadede karlı bir eylem olarak gözükse de orta ve uzun vadede müşteri kaybına neden olabilmektedir. Bu araştırmanın bulgularına göre yetersiz hizmet sunumu da müşterinin algıladığ1 riski artırabilmektedir. Dolayısıyla e-ticaret işlemlerinin bilişim teknolojileri altyapısını artırması ve uçtan uca yüksek müssteri denemeyi sağlaması bu riskin düşürülmesine katkı sunacaktır. Uygulamaya baktığımızda bu önerilerin kısmen uygulandığını ifade edebiliriz. Diğer bir bulgu ise işlem başarısızlığı algılanan riski artırmaktadır. Dolayısıyla satın alma sürecinden önce başlayıp satın alma sonrasındaki sürece kadar olan müşteri yolculuğu takip edilerek gerekli yerlerde müşteriyle iletişim sağlanmalıdır. Eğer işlem başarısızlığı riski minimum düzeye indirilmez ise oldukça önemli düzeyde bir müşteri kaybına neden olabilecektir. Sonuç olarak, risk sektörüne göre birçok risk parametresini içinde barındırmaktadır. Eğer e-ticaret işletmeleri müşterilerin alışveriş yapmasını istiyorlarsa ise risk düzeyini minimum düzeyde tutmaları büyük fayda sağlayacaktır. Bu çalışma ve önceki çalışmalar bu tezi destekleyecek önemli kanıtlar sunmaktadır.

$\mathrm{Bu}$ çalışmalarda bir takım kısıtlar bulunmaktadır. Bu çalışmada sadece algılanan risk ölçeği test edilmiştir. Dolaysıyla bu riskin sonuçları ile ilgili çalışmada herhangi bir amaç güdülmemiştir. Gelecek çalışmalarda algılanan riskin öncülleri ve sonuçları olabilecek değişkenler dahil edilerek pozitif ve negatif ilişkiler irdelenebilir. $\mathrm{Bu}$ çalışmada sektör fark etmeksizin e-ticaret deneyimi yaşamış müşteriler katılımcı olmuştur. Gelecek çalışmalarda sektör bazında irdelenerek sektörlere özgü bulguların 
elde edilebilir. $\mathrm{Bu}$ ölçeğin güvenirliği ve geçerliliği konusunda yapılan çalışmalar oldukça kısıtlıdır. Gelecek çalışmalarda farklı örneklem kitleleriyle çalışmalar yapılması geçerliliğe ve güvenirliğe katkı sağlayacaktır.

\section{Kaynakça}

Ali, F., Kim, W. G., Li, J. (Justin), \& Cobanoglu, C. (2018). A comparative study of covariance and partial least squares based structural equation modelling in hospitality and tourism research. International Journal of Contemporary Hospitality Management, 30(1), 416-435. https://doi.org/10.1108/IJCHM-082016-0409

Bagozzi, R. P., Yi, Y., \& Phillips, L. W. (1991). Assessing Construct Validity in Organizational Research. Administrative Science Quarterly, 36(3), 421-458. https://doi.org/10.2307/2393203

Bashir, S., Khwaja, M. G., Mahmood, A., Turi, J. A., \& Latif, K. F. (2021). Refining eshoppers' perceived risks: Development and validation of new measurement scale. Journal of Retailing and Consumer Services, 58, 102285.

Bauer, R. A. (1960). Consumer behavior as risk taking. Içinde R. S. Hancock (Ed.), Dynamic Marketing for a Changing World (ss. 389-398). American Marketing Association.

Bhatnagar, A., \& Ghose, S. (2004). Segmenting consumers based on the benefits and risks of Internet shopping. Journal of Business Research, 57(12), 1352-1360.

Chen, C. (2012). PRIS: A multiple-item scale for measuring perceived risk of internet shopping. Purdue University.

Desrochers, J., \& François Outreville, J. (2020). Perceived risk and insurance decision taking for small losses. Journal of Risk Research, 23(4), 447-460.

Dholakia, U. M. (1997). An Investigation of the Relationship Between Perceived Risk and Product Involvement. Advances in Consumer Research, 24(1), 159-167.

Dowling, G. R. (1986). Perceived risk: the concept and its measurement. Psychology \& Marketing, 3(3), 193-210.

Fornell, C., \& Larcker, D. F. (1981). Evaluating Structural Equation Models with Unobservable Variables and Measurement Error. Journal of Marketing Research, 18(1), 39-50. https://doi.org/10.1177/002224378101800104

Hair, J. F., Risher, J. J., Sarstedt, M., \& Ringle, C. M. (2019). When to use and how to report the results of PLS-SEM. European Business Review, 31(1), 2-24. 
Hawes, J. M., \& Lumpkin, J. R. (1986). Perceived risk and the selection of a retail patronage mode. Journal of the Academy of Marketing Science, 14(4), 37-42.

Henseler, J., Ringle, C. M., \& Sarstedt, M. (2015). A new criterion for assessing discriminant validity in variance-based structural equation modeling. Journal of the academy of marketing science, 43(1), 115-135.

Hussain, S., Ahmed, W., Jafar, R. M. S., Rabnawaz, A., \& Jianzhou, Y. (2017). eWOM source credibility, perceived risk and food product customer's information adoption. Computers in Human Behavior, 66, 96-102.

Jacoby, J., \& Kaplan, L. B. (1972). The Components of Perceived Risk. ACR Special Volumes, 382-393.

Lal, P. (2017). Analyzing determinants influencing an individual' s intention to use social commerce website. Future Business Journal, 3(1), 70-85.

Lutz, R. J., \& Reilly, P. J. (1974). An exploration of the effects of perceived social and performance risk on consumer information acquisition. ACR North American Advances, 1, 393-405.

Mello, S. C. B., \& Collins, M. (1998). Risk Perception And Industrial Buyer Differences. Encontro Nacional da ANPAD.

Naranjo-Zolotov, M., Turel, O., Oliveira, T., \& Lascano, J. E. (2021). Drivers of online social media addiction in the context of public unrest: A sense of virtual community perspective. Computers in Human Behavior, 106784.

$\mathrm{Ng}$, C. S.-P. (2013). Intention to purchase on social commerce websites across cultures: A cross-regional study. Information \& Management, 50(8), 609-620. https://doi.org/https://doi.org/10.1016/j.im.2013.08.002

Prasad, V. K. (1975). Socioeconomic product risk and patronage preferences of retail shoppers. Journal of Marketing, 39(3), 42-47.

Quintal, V. A., Lee, J. A., \& Soutar, G. N. (2010). Tourists' information search: the differential impact of risk and uncertainty avoidance. International Journal of Tourism Research, 12(4), 321-333.

Rosa, E. A. (2003). The logical structure of the social amplification of risk framework (SARF): Metatheoretical foundations and policy implications. The social amplification of risk, 47, 47-49.

Roselius, T. (1971). Consumer rankings of risk reduction methods. Journal of marketing, 35(1), 56-61.

Samadi, M., \& Yaghoob-Nejadi, A. (2009). A survey of the effect of consumers' 
perceived risk on purchase intention in e-shopping. Business Intelligence Journal, 2(2), 261-275.

Sarstedt, M., \& Cheah, J.-H. (2019). Partial least squares structural equation modeling using SmartPLS: a software review. Journal of Marketing Analytics, 7(3), 196202. https://doi.org/10.1057/s41270-019-00058-3

Sarstedt, M., Hair, J. F., Cheah, J.-H., Becker, J.-M., \& Ringle, C. M. (2019). How to specify, estimate, and validate higher-order constructs in PLS-SEM. Australasian Marketing Journal (AMJ), 27(3), 197-211.

https://doi.org/https://doi.org/10.1016/j.ausmj.2019.05.003

Stone, R. N., \& Grønhaug, K. (1993). Perceived risk: Further considerations for the marketing discipline. European Journal of marketing, 27(3), 39-50.

Tseng, S.-Y., \& Wang, C.-N. (2016). Perceived risk influence on dual-route information adoption processes on travel websites. Journal of Business Research, 69(6), 2289-2296. https://doi.org/https://doi.org/10.1016/j.jbusres.2015.12.044

Zhang, L., Tan, W., Xu, Y., \& Tan, G. (2012). Dimensions of perceived risk and their influence on consumers' purchasing behavior in the overall process of B2C. Içinde Engineering education and management (ss. 1-10). Springer. 